\title{
Šestisetleté výročí bitvy na Kulikovském poli: Rusofobie a eurasijství L. N. Gumileva v 80. letech 20. století
}

\section{The 600th anniversary of the Battle of Kulikovo: Russophobia and Eurasianism of L. N. Gumilev in the 1980s}

\author{
Michal Racyn / racyn@phil.muni.cz \\ Ústav slavistiky, Filozofická fakulta, Masarykova univerzita
}

\begin{abstract}
This paper focuses on selected historiography concepts of the soviet historian and ethnologist L. N. Gumilev (1912-1992). The main aim is to present Gumilev's revision of the Kulikovo battle (1380). Paper is based on his two articles published in 1980 on the occasion of the $600^{\text {th }}$ anniversary of the event. Primary sources are supplemented by Gumilev's correspondence deposited in Prague and St. Petersburg. Paper clarifies alleged Eurasianist aspects of Gumilev's articles and consequences of their ambivalent reception in the intellectual milieu of Russian nationalists.
\end{abstract}

\section{Keywords}

Nationalism, Eurasianism, USSR, L. N. Gumilev, Battle of Kulikovo, Soviet historiography

\footnotetext{
Tento výstup vznikl na Masarykově univerzitě $v$ rámci projektu Proměny reflexe ruského politického a společenského myšlení číslo MUNI/A/1114/2020 podpořeného z prostředkú účelové podpory na specifický vysokoškolský výzkum, kterou poskytlo MŠMT v roce 2021. Text vychází z připravovaného disertačního projektu zaměřeného na vývoj a proměny eurasijských koncepcí mezi lety 1945-1991 a také z diplomové práce věnované analýze písemného kontaktu mezi P. N. Savickým a L. N. Gumilevem. Srov. Racyn, Michal: Eurasijství P. N. Savického a L. N. Gumileva v kontextu jejich vzájemné korespondence. Masarykova univerzita. Filozofická fakulta. Brno 2018. Nepublikovaná diplomová práce.
} 


\section{Úvod}

Následující text je soustředěn na představení vybraných historiografických koncepcí sovětského historika a etnologa Lva Nikolajeviče Gumileva (1912-1992). Pozornost je věnována postoji ruských nacionalistů k argumentům, které Gumilev publikoval v roce 1980 u př́ležitosti šestisetletého výročí bitvy na Kulikovském poli (1380). Na základě detailního srovnání zjištěných poznatků bylo možné objasnit některé aspekty vnitřní názorové roztř́išstěnosti ruských nacionalistů a přiblížit důsledky jejich ambivalentních reakcí na práce Gumileva v předposlední dekádě 20. století.

Studie je založena na analýze diskursu ruského nacionalistického hnutí v první polovině 80 . let 20. století. Analýza vychází z komparace vybrané primární literatury soustředěné na reflexi kulikovské bitvy. Hlavní pozornost je soustředěna na příspěvky Gumileva otištěné v roce 1980 v časopisech Ogonek a Dekorativnoje iskusstvo. ${ }^{1}$ Tyto texty budou srovnány s publikacemi ruských nacionalistů reagujících na teze představené Gumilevem. Jedná se zejména o sérii článků sovětského historika a spisovatele Vladimíra Aleksejeviče Čivilichina (1928-1984), publikovaných v nacionalistickém časopise Naš sovreme$n n i k .{ }^{2}$ Další zdroj primární literatury představují texty historika Apollona Grigor’jeviče Kuz'min $^{a}$ (1928-2004), ${ }^{3}$ literárního kritika Vadima Valerianoviče Kožinova (1930-2001) ${ }^{4}$ a spisovatele Jurije Mefodjeviče Borodaje (1934-2006). ${ }^{5}$ Všechny jmenované osobnosti v průběhu 80. let aktivně působily v prostředí ruských nacionalistů a podrobně reflektovaly svůj postoj k tezím Gumileva. Zmíněnou primární literaturu doplní relevantní soukromá korespondence mezi Gumilevem a dvěma předními představiteli meziválečného eurasijského hnutí - geografem Petrem Nikolajevičem Savickým (1895-1968) a historikem Georgijem Vladimirovičem Vernadským (1887-1973). Dokumenty se v současnosti nachází ve Slovanské knihovně v Praze $^{6}$ a v muzeu L. N. Gumileva v Petrohradu (filiál muzea Anny Achmatovové $)^{7}$ a představují unikátní a dosud jen částečně probádaný zdroj informací.

1 Články jsou dostupné ve dvou sbornících věnovaných Gumilevovým pracím. Viz Gumilev, Lev Nikolajevič: Ėcho kulikovskoj bitvy. In: Černaja legenda. Edd. L. N. Gumilev - V. Manjagin. Moskva 2006, s. 296-407; Gumilev, Lev Nikolajevič: God Roždenija 1380... In: Lev Gumilev. Teorija ètnogeneza: Velikoje otkrytije ili mistifikacija? Ed. M. Zil'bert. Moskva 2013, s. 155-171.

2 V roce 1988 byly tyto články souhrnně publikovány v rámci samostatné monografie. Viz Čivilichin, Vladimir Aleksejevič: Pamjat': Roman-èsse v dvuch knigach (kniga vtoraja). Moskva 1988.

3 V roce 1989 byl zmíněný př́íspěvek otištěn v rámci souhrnného sborníku. Srov. Kuz'min, Apollon Grigorjevič: Svjǎ̌̌ennyje kamni pamjati: O romane Vladimira Čivilichina ,Pamjat'. In: K kakomu chramu iščem my dorogu? Istorija glazami sovremennika. Ed. A. G. Kuz'min. Moskva 1989.

4 Př́íspěvky byly otištěny také ve sborníku z roku 2002. Viz Kožinov, Vadim Valerianovič: I nazovet menja vsjak suščij v nej jazyk... Zametki o duchovnom svojeobrazii Rossii. In: O russkom nacional'nom soznanii. Izbrannyje stat'ji o naiboleje aktual'nych voprosach Rossijskogo gosudarstva. Edd. V. V. Kožinov - A. Ul'jašov. Moskva 2002, s. 133-180.

5 Borodaj, Jurij Mefodjevič: Ètničeskije kontakty i okružajǔ̌čaja sreda. Priroda. 1981, (9). 82-85.

6 Slovanská knihovna (SLK), Praha. Fond speciálních sbírek Slovanské knihovny. Sg. T-SAV.

7 Muzej-kvartira L’va Gumileva - filial Muzeja Anny Achmatovoj (MKLG-MAA), Sankt-Peterburg. Sg. KPVKh-18928. 
Primární texty jsou doplněny o vybrané sekundární zdroje, soustředěné na několik vzájemně propojených témat. Analýzu šestisetletého výročí kulikovské bitvy již v roce 1984 představil americký historik Charles J. Halperin. V souhrnné recenzi vybraných studií sovětských akademiků autor vypozoroval řadu názorových rozporů. Většina představených textů však podle jeho názorů jednoznačně směřovala k nadhodnocování významu kulikovské bitvy. ${ }^{8} \mathrm{~K}$ dobové reflexi ruského nacionalistického hnutí byla využita publikace Johna B. Dunlopa z roku $1983 .{ }^{9} \mathrm{~S}$ větším časovým odstupem postoj sovětského režimu k aktivitám ruských nacionalistů detailně představil Yitzhak Brudny ve své stěžejní monografii z roku 1998. ${ }^{10}$ Publikační aktivitě nacionalistického časopisu Naš sovremennik v období mezi lety 1981-1991 se v roce 2003 věnoval Simon Crosgrove. ${ }^{11} \mathrm{~V}$ ruském akademickém prostředí ruský nacionalismus zkoumal zejména Nikolaj Aleksandrovič Mitrochin. Kromě detailního vhledu do aktivity ruských nacionalistů v první polovině 80. let autor zhodnotil také výsledky předcházejícího (ruského i zahraničního) výzkumu dané problematiky. ${ }^{12} \mathrm{Na}$ analýzu ruského nacionalismu v prostředí Sovětského svazu se v posledních letech zaměřil také Aleksandr Jur’jevič Koževnikov a své poznatky shrnul v panoramatické monografii z roku 2017. ${ }^{13}$

Myšlenkám L. N. Gumileva se v několika významných příspěvcích věnoval Mark Bassin. Je potřeba poukázat zejména na jeho studii z roku 2015 soustředěnou právě na Gumilevovu reflexi kulikovské bitvy. ${ }^{14} \mathrm{~K}$ tomuto tématu se autor vrátil také v samostatné monografii zaměřené na detailní představení nejdůležitějších Gumilevových koncepcí. ${ }^{15} \mathrm{~V}$ rámci domácího ruského výzkumu bylo Gumilevovi již od 90 . let 20. století věnováno velmi rozsáhlé množství studií. Řada zásadních textů reflektujících specifické aspekty Gumilevova života a jeho vědeckých koncepcí je soustředěna v rozsáhlé antologii ze série Pro et contra. Zde bylo otištěno množství obtížně dostupných příspěvků a také kompletní bibliografie Gumilevových oficiálně publikovaných prací. ${ }^{16}$ Aktuálně nejucelenější pohled na Gumilevův soukromý i profesní život představil v roce 2012 Sergej Stanislavovič Beljakov. Autorův postoj k některým aspektům Gumilevova vědeckého

8 Halperin, Charles J.: The Six-Hundredth Anniversary of the Battle of Kulikovo Field, 1380-1980. In: Soviet Historiography. Canadian-American Slavic Studies. 1984, 18(3), 298-310.

9 Dunlop, John B.: The faces of contemporary Russian nationalism. Princeton 1983.

10 Brudny, Yitzhak M.: Reinventing Russia: Russian nationalism and the Soviet state, 1953-1991. Cambridge, Mass: Harvard University Press, 1998.

11 Cosgrove, Simon: Russian nationalism and the politics of soviet literature: the case of Nash sovremennik 19811991. Basingstoke 2004.

12 Mitrochin, Nikolaj Aleksadnrovič: Russkaja partija. Dviženije russkich nacionalistov v SSSR 1953-1985. Moskva 2003, s. 13-40.

13 Koževnikov, Aleksandr Jurijevič: Russkij patriotizm i sovetskij socializm. Moskva 2017.

14 Bassin, Mark: Narrating Kulikovo: Lev Gumilev, Russian Nationalists and the Troubled Emergence of Neo-Eurasianism. In: Between Europe \& Asia: the origins, theories, and legacies of Russian Eurasianism. Edd. M. Bassin - S. Glebov - M. Laruelle. Pittsburgh 2015.

15 Bassin, Mark: The Gumilev mystique: biopolitics, Eurasianism, and the construction of community in modern Russia. Ithaca 2016.

16 Viz Kozyreva, Marina Georgievna: Bibliografija pervych publikacij sočinenij L. N. Gumileva. In: L. N. Gumilev: Pro et contra. Ed. D. K. Burlaka. Sankt-Peterburg 2012, s. 842-860. 
odkazu však není zcela objektivní. V řadě případů Beljakov se značným despektem pohlíží na jeho pozitivní vztah k meziválečnému eurasijství a současně sympatizuje právě s argumenty některých ruských nacionalistů z období 80 . let 20. století. $^{17}$

\section{Ruský nacionalismus v druhé polovině 20. století}

Aktivita ruských nacionalistů v druhé polovině 20. století úzce souvisela s významnými politickými událostmi, které probíhaly v Sovětském svazu po smrti J. V. Stalina. Nástup N. S. Chruščova přinesl řadu politických a ideologických změn, ke kterým nacionalisticky orientovaní intelektuálové nemohli zůstat lhostejní. Zejména Chruščovovy ostré útoky na pravoslavnou církev vyvolávaly v prostředí ruských nacionalistů silné protirežimní nálady. Jak zdůrazňuje J. Dunlop, proticírkevní kampaň sehrála ve formování ruského nacionalismu důležitou roli a do určité míry sjednotila část nacionalistů s masami pravoslavných věřících. ${ }^{18}$

Dalším důležitým faktorem se stala oficiálně propagovaná tendence k vytvoření jednolité komunistické společnosti, ve které by zanikly jednotlivé národy a jejich kulturní specifika. Tato tendence se ocitla v přímé opozici vůči Stalinem propagované tzv. družbě národů a znepokojovala nejen národnostní menšiny Sovětského svazu, ale také etnické Rusy. ${ }^{19}$ Otázka ohledně postavení Rusů v rámci Sovětského svazu rezonovala především $\mathrm{v}$ radikálně naladěných skupinách. Zejména tzv. státníci zdůrazňovali nevýhodné postavení etnických Rusů na úkor neruských národů Sovětského svazu. ${ }^{20}$

Probíhající destalinizace navíc přispěla k omezenému, ale zřetelně viditelnému uvolnění cenzury. Tato skutečnost napomohla k oživení nejen ruských nacionalistů, ale také liberálně a prozápadně smýšlejících intelektuálů. Chruščovova provokace nacionalisticky orientovaných skupin a současné uvolnění prostoru pro argumenty liberální opozice ve výsledku přivedly k nebezpečnému ideologickému a politickému napětí, které se pokusil zmírnit až Chruščovův nástupce - L. I. Brežněv.

$\mathrm{S}$ příchodem Brežněva došlo v prostředí sovětských intelektuálů k několika důležitým změnám. Brežněvova snaha o zvrácení a utlumení dosavadních reforem vyvolala značné znepokojení napříč všemi skupinami sovětských intelektuálů. Pobouření liberální prozápadně orientované frakce vedlo k vytvoření tzv. ruského demokratického hnutí, které vyvolalo silný ohlas a podporu zejména v západní Evropě. ${ }^{21}$ Ve snaze eliminovat potenciální dopad těchto protirežimně naladěných tendencí se Brežněv uchýlil k cílené materiální podpoře ruských nacionalistů. Z jeho pohledu nacionalistické skupiny představovaly kriticky naladěné, ale dobře kontrolovatelné hnutí, jehož aktivita měla být v první řadě namířena k utlumení nežádoucích reforem, započatých Chruščovem na konci 50.

17 Beljakov, Sergej Stanislavovič: Gumilev syn Gumileva. Moskva 2013, s. 565-567.

18 Dunlop, J.: The faces of contemporary Russian nationalism, s. 30.

19 Koževnikov, A. J.: Russkij patriotizm i sovetskij socializm s. 412.

20 Shlapentokh, Vladimir: Soviet intellectuals and political power. The post-Stalin era. New Jersey, s. 212. Viz také: Bassin, M. The Gumilev mystique, s. 178. 
let, a také jako protiváha k sílícímu liberálnímu hnutí. ${ }^{22}$ Y. Brudny tuto komplikovanou a ve výsledku kontraproduktivní tendenci označil jako tzv. politiku inkluze. ${ }^{23}$ Její počátek a ukončení se do značné míry překrývá s vládou Brežněva a vztahuje se $\mathrm{k}$ časovému období od druhé poloviny 60 . let až do počátku 80 . let 20 . století.

Na směřování a vývoj jednotlivých nacionalistických skupin měla Brežněvova inkluzivní politika zcela zásadní dopad. Hlavní představitelé hnutí pravidelně získávali řadu prestižních literárních ocenění a jejich publikace byly distribuovány v statisícových nákladech..$^{24}$ Tento prrístup vzbudil v prostředí ruských nacionalistů velká očekávání a řadu př́i slibů, které však ze strany Sovětského svazu nebyly nikdy naplněny. Ve výsledku oficiální podpora publikační aktivity ruských nacionalistů výrazně posílila jejich sebevědomí. Poskytnuté materiální zázemí však nezměnilo jejich rezervovaný postoj k tehdejší oficiální politice tak, jak to předpokládal Brežněv. ${ }^{25}$

V průběhu 60. let se v sílícím prostředí ruského nacionalistického hnutí zformovalo několik výrazných skupin. ${ }^{26}$ Do první skupiny lze zařadit tzv. liberální nacionalisty, ostře kritizující Stalinovu vládu a sympatizující s některými politickými a kulturními tendencemi západní Evropy. Druhou skupinu zastupovali konzervativně orientovaní intelektuálové, spříznění s literárním hnutím tzv. vesnické prózy. Třetí výrazná skupina ruských nacionalistů byla soustředěna kolem časopisů Naš sovremennik a Molodaja gvardija. Jejich hlavní náplní se stala radikální kritika potenciálního ekonomického a politického sblížení se Západem a systematické zdůrazňování politické a kulturní samostatnosti ruského etnika a jeho vůdčí pozice v rámci Sovětského svazu. ${ }^{27}$ Konkrétní představy všech zmíněných skupin o dalším směřování Ruska a celého Sovětského svazu se z pochopitelných důvodů velmi často ocitaly ve vzájemné opozici. Jejich obecné tendence však byly i nadále formovány nikoliv jako součást tehdejší státní ideologie, ale jako její potenciální náhrada.

Zásadní rozkol mezi nenaplněnými očekáváními ruských nacionalistů a reálným směřováním oficiální sovětské politiky přišel bezprostředně po smrti Brežněva v roce 1982.28 Ještě předtím však ruští nacionalisté získali dvouleté období téměř bezprecedentní publikační a názorové svobody. S koncem Brežněvovy vlády totiž souvisela jedna zásadní kulturní a společenská událost, která (nejen) v ruských nacionalistických kruzích posloužila jako ideální záminka pro otevření vyhraněné diskuze ohledně historických kořenů ruského národa a jeho dalšího směřování - jedná se o šestisetleté výročí ikonické a v ruském prostředí notoricky známé bitvy na Kulikovském poli (1380). ${ }^{29}$ Při hodnocení této události se naplno odkryla také vnitřní názorová roztřrišstěnost jednotlivých skupin ruských nacionalistů. Důležitou roli zde sehrály právě práce sovětského historika a etnologa

22 Koževnikov, A. J.: Russkij patriotizm $i$ sovetskij socializm, s. 415.

23 Brudny, Y.: Reinventing Russia, s. 16.

24 Cosgrove, S.: Russian nationalism and the politics of soviet literature, s. 18.

25 Brudny, Y.: Reinventing Russia, s. 18.

26 Tamtéž, s. 9.

27 Brudny, Y.: Reinventing Russia, s. 24.

28 Koževnikov, A. J.: Russkij patriotizm i sovetskij socializm s. 474, Srov. Brudny, Y.: Reinventing Russia, s. 192, Srov. Mitrochin, N. A.: Russkaja partija. Dviženije russkich nacionalistov v SSSR 1953-1985, s. 552-556. 
L. N. Gumileva, který v roce 1980 publikoval dva kontroverzní články zaměřené na revizi kulikovské bitvy. Tyto texty rozpoutaly ostrou názorovou výměnu, která ve výsledku ještě více prohloubila vnitřní rozpory ruských nacionalistů a současně podnítila důslednou režimní protireakci.

\section{N. Gumilev a jeho pozice v rámci sovětského intelektuálního prostředí}

Lev Nikolajevič Gumilev bezesporu patří mezi velmi výrazné a viditelné osobnosti sovětského intelektuálního prostředí 2. poloviny 20. století. Jako syn dvou prominentních básníků předrevolučního Ruska (Anny Achmatovové a Nikolaje Gumileva) byl L. N. Gumilev již od 30. let pravidelně perzekuován komunistickým režimem.

V průběhu 30. let byl Gumilev donucen několikrát přerušit vysokoškolské studium na Leningradské univerzitě. V roce 1938 došlo k jeho obvinění z antisovětské činnosti a odsouzení k pětiletému odnětí svobody. Druhé odsouzení následovalo v roce 1949. Ve výsledku Gumilev strávil v sovětských pracovních a nápravných táborech více než deset let a jeho akademická a pracovní kariéra začala až v druhé polovině 50 . let, krátce po návratu do Leningradu. ${ }^{30} \mathrm{I}$ v průběhu následujících let se Gumilev nadále potýkal s režimní cenzurou a publikace jeho textů byla systematicky utlumována. ${ }^{31}$ Až do počátku 80. let byl Gumilev poměrně marginálním autorem a jeho práce zůstávaly mimo zorné pole široké veřejnosti. ${ }^{32}$ Jak ovšem zdůrazňují někteří badatelé, navzdory všem předpokladům Gumilev nikdy neprojevil sympatie k liberální anti-sovětsky naladěné opozici a snažil se zůstávat mimo jakékoliv politické dění. ${ }^{33}$ Navzdory této snaze však již v průběhu 60 . let 20. století jeho práce získaly značný ohlas ve zmíněném poststalinském prostředí ruských nacionalistů. V následujících desetiletích se jejich postoje ke Gumilevovým myšlenkám výrazně proměňovaly, a kromě řady kladných reakcí zahrnovaly také velmi ostrou kritiku. ${ }^{34}$ Ke kulminaci této názorové roztřŕšš̌nosti došlo na počátku 80. let 20. století, právě v souvislosti s oslavami šestisetletého výročí kulikovské bitvy.

30 Beljakov, S. S.: Gumilev syn Gumileva, s. 318-324. Srov. Bassin, M.: The Gumilev mystique, s. 15.

31 Sám Gumilev tuto situaci detailně přiblížil v polovině 80. let, viz Gumilev, L. N.: Mechanizm zažima publikacij L. N. Gumileva, doktora istoričeskich nauks $1961 \mathrm{~g}$. za period s 1975 po $1985 \mathrm{~g}$. In: Lev Gumilev. Teorija ètnogeneza: Velikoje otkrytije ili mistifikacija? Ed. M. Zil’bert. Moskva 2013, s. 647.

32 Bassin, M.: The Gumilev mystique, s. 177.

33 Beljakov, S. S.: Gumilev syn Gumileva, s. 672.

34 Bassin, M.: Narrating Kulikovo, s. 179. Již v průběhu 60. let 20. století Gumilev získal pozornost ruských nacionalistů svými studiemi zaměřenými na dějiny tzv. Chazarského kaganátu. Hlavním tématem diskuse se v tomto případě staly Gumilevovy antisemitské výpady vycházející z analýzy politického vývoje Chazarského kaganátu, který se v průběhu 8. století údajně ocitl pod kontrolou židovské komunity. Postoj sovětského režimu k výzkumu chazarských dějin se v průběhu 20. století několikrát významně proměnil a ovlivnil směřování řady sovětských akademiků. Jako příklad lze uvést práce sovětského archeologa a historika Michaila Illarionoviče Artamonova. V první polovině 50. let byl Artamonov obviněn z nepřiměřeného nadhodnocování historického významu Chazarské říše a jeho dřivější práce byly zcela diskreditovány. Pod režimním nátlakem historik provedl důslednou revizi svých předchozích studií a v roce 1962 vydal stěžejní monografii po názvem Istorija Chazar. Na přípravě dané publikace se významně podílel také Gumilev. Viz 


\section{Šestisetleté výročí kulikovské bitvy v textech ruských nacionalistů}

V dobovém prostředí sovětské historiografie byla reflexe kulikovské bitvy spojena s pevně ukotveným narativem. Podle většiny sovětských historiků vítězství moskevského knížete Dmitrije Ivanoviče nad tatarským emírem Mamajem představovalo v dějinách Ruska zcela zásadní a přelomovou událost, která v konečném důsledku přinesla kýžené osvobození od devastující tatarské nadvlády. ${ }^{35}$ Tendence k nadhodnocování kulikovské bitvy vyvrcholila právě v rámci oslav jejího šestisetletého výročí a lze ji vypozorovat také v řadě příspěvků ruských nacionalisticky orientovaných historiků a intelektuálů. Jak poukazuje Y. Brudny, práce ruských nacionalistů zaměřené na danou událost reflektovaly několik zásadních témat. $\mathrm{V}$ řadě případů se však argumenty konkrétních osobností nacházely ve velmi výrazné opozici. ${ }^{36}$

Jako první příklad lze uvést jejich překvapivě ambivalentní pohled na historický význam ruské pravoslavné církve a její roli v kontextu kulikovské bitvy. ${ }^{37}$ Historik Dmitrij Sergejevič Lichačov (jeden z nejviditelnějších a nejvlivnějších představitelů liberálně orientované skupiny ruských nacionalistů) zdůrazňoval, že vítězství na Kulikovském poli bylo významně podpořeno duchovním oživením ruského národa. Podle jeho názoru v roce 1380 zvítězila nejen ruská armáda, ale především ruská idea a morální síla reprezentovaná pravoslavnou církví. Přímým důsledkem této události se stalo obnovení před-mongolské tradice Kyjevské Rusi a návrat k jejím kulturním a duchovním hodnotám. ${ }^{38}$ Zcela odlišné argumenty přicházely z tábora radikálně orientovaných nacionalistů. V opozici vưči názorům D. S. Lichačova vystoupili např́klad historici Apollon Grigorjevič Kuz'min a Vadim Viktorovič Kargalov. V jejich textech byla role pravoslavné církve vnímána v překvapivě negativním kontextu. Mnohem větší pozornost autoři věnovali objasnění odkazu původního polyteistického náboženství východních Slovanů, ve kterém se oba historici pokusili odhalit skutečné duchovní a morální kořeny ruského národa. ${ }^{39}$

Druhým významným tématem se stala revize historických vztahů mezi Ruskem a Západem. Výročí kulikovské bitvy bylo některými nacionalisty využito zejména ke zdůraznění zásadní historické role, kterou Rusko sehrálo při záchraně západního světa před zničující tatarskou invazí. Tuto pozici zastával například Vladimír Aleksejevič Čivilichin na stránkách nacionalistického časopisu Naš sovremennik. ${ }^{40}$ I zde se ovšem projevila silná názorová roztř́išsěnost. Pozici liberálně orientovaných ruských nacionalistů zastupoval například historik Gelian Michajlovič Prochorov, zdůrazňující pozitivní význam kontaktu se západní Evropou. Podle jeho názoru v průběhu 18. a 19. století Rusko dokázalo skloubit

Rossman, Vadim: Lev Gumilev, Eurasianism and Khazaria. European Jewish Affairs. Routledge Press, 2002, 32(1), s. 34.

35 Halperin, Ch.: The Six-Hundredth Anniversary of the Battle of Kulikovo Field, 1380-1980. Soviet Historiography, s. 298.

36 Brudny, Y.: Reinventing Russia, s. 185.

37 Tamtéž, s. 182.

38 Tamtéž, s. 183.

39 Tamtéž, s. 184.

40 Čivilichin, V. A.: Pamjat', s. 620. 
dědictví východního a západního světa a převzít z obou kultur ty nejdůležitější hodnoty. Přerušení kontaktu se Západem mohlo vést k nenávratnému narušení této cenné rovnováhy. ${ }^{41}$

Zcela zásadní spor mezi jednotlivými nacionalistickými skupinami se však rozhořel v souvislosti s revizionistickými tezemi L. N. Gumileva. V nesourodém prostředí ruských nacionalistů jeho texty vyvolaly velmi ostré a protichůdné reakce. Na jedné straně byl Gumilev označován za tzv. rusofoba a propagátora nebezpečných polozapomenutých eurasijských koncepcí. ${ }^{42} \mathrm{Na}$ druhou stranu, právě v nacionalistickém prostředí Gumilev ve výsledku získal řadu podporovatelů a již na počátku 90. let se jeho texty začaly pravidelně objevovat na stránkách časopisu Naš sovremennik. ${ }^{43} \mathrm{~V}$ širším kontextu Gumilevovy texty vyvolaly řetězovou reakci, která v konečném důsledku přispěla k eskalaci napětí nejen mezi samotnými ruskými nacionalisty, ale také k nežádoucímu zhoršení jejich vztahů s oficiálním sovětským režimem.

\section{N. Gumilev a jeho revize kulikovské bitvy}

Dva články, které Gumilev publikoval v roce 1980 na stránkách časopisů Ogoněk a Dekorationoje iskusstvo patří mezi jedny z jeho nejkontroverznějších a nejdiskutovanějších textů. V prvním článku nazvaném God Roždenija 1380... Gumilev představil zcela nový pohled na okolnosti dané události a radikálně přehodnotil politické vztahy, které na konci 14. století panovaly mezi jednotlivými ruskými knížectvími a Zlatou hordou. ${ }^{44}$ Interpretaci kulikovské bitvy Gumilev úzce propojil s vnitřní politickou situací Zlaté hordy, pod jejíž kontrolou se ve 14. století nacházela značná část ruského území. Po státním převratu v roce 1312 se moci chopil chán Uzbek. Pod jeho vládou byl islám prohlášen za státní náboženství, což podle Gumileva zásadním způsobem narušilo, do té doby zcela pozitivní (sic!) vztahy Zlaté hordy s ruskými knížaty. ${ }^{45} \mathrm{~V} 70$. letech 14 . století tuto krizi ještě výrazněji prohloubil emír Mamaj. V jeho osobě Gumilev spatřoval uzurpátora, který nelegálně získal kontrolu na Zlatou hordou díky podpoře římskokatolické Janovské republiky a dalších prozápadně orientovaných nepřátel Moskevské Rusi. ${ }^{46} \mathrm{~V}$ roce 1380 Moskevská Rus vystoupila proti Mamajovým vojskům pod vedením Dmitrije Ivanoviče (Donského). Na straně Dmitrije se však podle Gumileva ocitl ještě jeden překvapivý spojenec. Jednalo se o právoplatného chána Tochtamyše - hlavního Mamajova oponenta a vůdce opoziční frakce tzv. Bílé hordy. ${ }^{47}$ Podle Gumilevovy interpretace tudíž na Kulikovském poli došlo

41 Cit. dle Brudny, Y.: Reinventing Russia, s. 184.

42 Čivilichin, V. A.: Pamjat', s. 592. Srov. Kuz'min, A. G.: Svjaščennyje kamni pamjati, s. 242.

43 Viz Gumilev, L. N.: „Menja nazyvajut jevrazijcem... “. Naš sovremennik: Literaturno-Chudožestvennyj i Obščestvenno-Političeskij Ježemesjačnyj Žurnal. 1991, (1), 132-141.

44 Gumilev, L. N.: God Roždenija 1380... In: Lev Gumilev. Teorija ètnogeneza: Velikoje otkrytije ili mistifikacija? Red. M. Zil'bert. Moskva 2013, s. 158.

45 Tamtéž, s. 160.

46 Gumilev, L. N.: God Roždenija 1380..., s. 163.

47 Tamtéž, s. 159. 
ke střetu, ve kterém na jedné straně vystupovala Moskevská Rus podpořená legitimním chánem Tochtamyšem a na straně druhé se nacházel prozápadně orientovaný emír Mamaj, spoléhající na podporu litevských vojsk a Janovské republiky. ${ }^{48} \mathrm{Z}$ tohoto hlediska tedy Dmitrij Ivanovič na Kulikovském poli bojoval nikoli proti tatarské nadvládě, ale proti potenciální západoevropské intervenci, která ohrožovala Moskevskou Rus prostřednictvím Mamajovy uzurpátorské vlády.

V druhém článku nazvaném Ėcho kulikovskoj bitvy Gumilev opět zopakoval většinu výše uvedených argumentů a důsledněji zasadil kulikovskou bitvu do kontextu své vlastní teorie etnogeneze. Podle jeho názoru vítězství Dmitrije Ivanoviče nad Mamajem definitivně sjednotilo jednotlivá ruská knížectví a vyústilo ve vznik jednotného ruského etnosu. ${ }^{49}$

\section{Útoky ruských nacionalistů na Gumilevovy teze}

Gumilevova radikální interpretace kulikovské bitvy záhy rozpoutala bouřlivou diskusi, která nejvýrazněji rezonovala právě v prostředí ruských nacionalistů. Již v průběhu roku 1980 proti Gumilevovým názorům vystoupil spisovatel V. A. Čivilichin. ${ }^{50}$ Jeho útok se stal součástí několikadílné série textů, které byly v průběhu let 1980-1982 publikovány v časopise Naš souremennik a následně byly otištěny ve dvoudílném esejistickém románu Pamjat.

V těchto rozsáhlých textech, pojednávajících o tisícileté ruské historii, Čivilichin nevybočoval z mantinelů oficiální sovětské historiografie a období tatarské nadvlády považoval za jednu z nejbolestivějších kapitol ruských dějin. ${ }^{51}$ Gumilevova idealizovaná interpretace rusko-tatarských vztahů Čivilichina naprosto pobouřila. ${ }^{52}$ Podle Čivilichinova názoru Gumilev zcela záměrně opovrhoval historickými fakty a zásadním zpo̊sobem deformoval jejich význam..$^{53}$ Neméně důležitým bodem jeho kritiky se stala asociace Gumilevových myšlenek s meziválečným eurasijským hnutím, ke kterému spisovatel projevoval stejnou míru antipatie. Představitelé meziválečného eurasijského hnutí se podle Čivilichina usilovně snažili distancovat ruský národ od kořenů před-mongolské Rusi a zcela ignorovali její ekonomický, sociální, politický a kulturní odkaz. ${ }^{54}$

V lednu 1982 se na stranu Čivilichina přidal historik A. G. Kuz'min, který svoje antigumilevské výpady prezentoval v rámci recenze zmíněného Čivilichinova románu, která byla otištěna na stránkách dalšího nacionalistického časopisu Molodaja gvardija. ${ }^{55}$ Podle Kuz’mina jednou z největších zásluh Čivilichinovy práce bylo odhalení spekulativní

48 Tamtéž, s. 161.

49 Gumilev, L. N.: Ècho kulikovskoj bitvy, s. 307.

50 Bassin, M.: Narrating Kulikovo, s. 179.

51 Čivilichin, V. A.: Pamjat', s. 592.

52 Tamtéž, s. 593.

53 Čivilichin, V. A.: Pamjat', s. 595.

54 Tamtéž, s. 621.

55 Kuz'min, A. G.: Svjaščennyje kamni pamjati, s. 243. 
povahy Gumilevových tezí. ${ }^{56}$ Kuz'min důrazně útočil také na Gumilevův výklad etnogeneze a na jeho selektivní a neprofesionální přístup k historickým pramenům, které Gumilev údajně záměrně deformoval a uměle vytvářel podle vlastních potřeb. ${ }^{57}$ Stranou opět nezůstala ani kritika meziválečného eurasijství, které podle Kuz’mina představovalo nebezpečný typ rusofobie, kterou Gumilev bez jakýchkoliv zábran propagoval ve svých textech. $^{58}$

\section{Eurasijství L. N. Gumileva v kontextu jeho historiografických prací}

Právě Čivilichin a Kuz'min jako jedni z prvních sovětských intelektuálů poukázali na přítomnost dle jejich názorů nebezpečných a ideologicky závadných eurasijských tendencí v Gumilevových pracích. Nicméně, jejich kritika byla oproštěna od hlubšího kontextu, v jehož rámci byl Gumilev skutečně obeznámen s uvedenými eurasijskými myšlenkami. Oba výše zmínění kritici asociovali Gumileva s meziválečným eurasijstvím pouze ve velmi hrubých obrysech, což ve výsledku vedlo k celé řadě zkreslených závěrů.

Sám Gumilev se ve skutečnosti velice často nacházel spíše v opozici vůči původním eurasijským koncepcím. Paradoxně právě v místech, kde Čivilichin a Kuz’min zdůrazňovali jeho eurasijství, je možné vypozorovat Gumilevův zásadní odklon od původních tezí tohoto meziválečného hnutí. Jak poukazuje Mark Bassin, představitelé původního eurasijství (navzdory vlastnímu poměrně radikálnímu revisionismu) nikdy nezpochybňovali existenci tatarské nadvlády jako takové. Pojem jho (neboli jařmo) byl nedílnou součástí eurasijského slovníku. Geograf a ekonom P. N. Savickij a další členové eurasijského hnutí jej vnímali jako zcela adekvátní vyjádření rusko-tatarských vztahů v období mezi 13. a 15. stoletím. ${ }^{59}$ Již v roce 1922, v jednom ze svých prvních eurasijských textů, Savickij prezentoval tezi, ve které přirovnal tatarskou invazi k ohnivé peci, ve které byla vykována ruská duchovní svébytnost. ${ }^{60} \mathrm{O}$ několik let později podobným způsobem nahlížel na rusko-tatarské vztahy také další představitel eurasijského hnutí - N. S. Trubeckoj. Podle jeho názoru, tatarský vpád vyvolal na Rusi silný psychologický a duchovní otřes. ${ }^{61}$ Negativní důsledky tatarského vpádu nezamlčoval ani přední historik eurasijského hnutí G. V. Vernadskij, který danou událost zasadil do kontextu své vlastní teze o tzv. boji mezi stepí a lesem. ${ }^{62}$

56 Tamtéž, s. 242.

57 Tamtéž, s. 247.

58 Tamtéź, s. 248.

59 Bassin, M.: Narrating Kulikovo, s. 173.

60 Savickij, Petr Nikolajevič: Step’ i osedlost'. In: Petrenko, J. L. Petr Nikolajevič Savickij: Izbrannoje, s. 172. Srov. SLK. Sg. T-SAV. Kart. č. II/C. Korespondence odeslaná jednotlivým osobám. Inv. č. 87/V. Gumilev, Lev Nikolajevič, Leningrad, f. 5.

61 Trubeckoj, Nikolaj Sergejevič: Nasledije Čingischana: Vzgljad na russkuju istoriju ne s Zapada, a s Vostoka. In: Trubeckoj N. S.: Istorija. Kul'tura. Red. V. M. Živov. Jazyk, s. 211.

62 Vernadskij, Georgij Vladimirovič: Načertanije russkoj istorii. 3-je izd. Moskva 2008, s. 26. Srov. MKLGMAA. Sg. KPVKh-18928. Vernadskij G. V. Pis'mo L. N. Gumilevu. N’ju-Chejven 9 dekabrja 1972, f. 21. 
V př́padě Gumileva však byla situace velmi odlišná. Jeho radikální interpretace kulikovské bitvy totiž úzce souvisela s tzv. černou legendou, podle které tatarská invaze na ruské území byla pouhým mýtem, na jehož vzniku a šírení měla největší podíl západní Evropa. ${ }^{63}$ Podle jeho názoru na ruské území nebylo uvaleno žádné jho a mezi ruským a tatarským obyvatelstvem vždy existoval kladný vztah a vzájemná sympatie, kterou Gumilev v rámci vlastní teorie etnogeneze označoval pojmem pozitivní komplementárnost. ${ }^{64} \mathrm{~V}$ jeho pojetí reprezentovaly rusko-tatarské vztahy určitý typ symbiózy, v jejímž rámci Tataři ochraňovali ruské území od negativního vlivu západoevropských mocností. ${ }^{65} \mathrm{Z}$ pohledu Gumileva tato symbióza byla narušena výše zmíněnou epizodickou vládou chána Uzbeka a uzurpátora Mamaje. Po porážce Mamaje na Kulikovském poli se však rusko-tatarské vztahy opět stabilizovaly. Od této kontroverzní teze Gumileva neodradila ani skutečnost, že již v roce 1382 chán Tochtamyš (jeden z domnělých spojenců Dmitrije Ivanoviče při bitvě na Kulikovském poli) sám zaútočil na Moskvu a vypálil celé město. Z Gumilevova pohledu však Tochtamyšův útok představoval pouze ojedinělý jev vyprovokovaný skupinou suzdalských knížat. ${ }^{66}$

Svoji interpretaci rusko-tatarských vztahů Gumilev ve výsledku zasadil do mnohem širšího kontextu. Zejména ve svých pozdějších textech historik zdůrazňoval, že v průběhu následujících 500 let černá legenda hluboce zakořenila v západoevropské mysli. Podle jeho názoru byl na základech této mystifikace postupně vybudován nebezpečný evropocentrismus, učení o tzv. historických a nehistorických národech, rasismus i neoprávněné teze o kulturní a politické zaostalosti Ruska. Podle jeho slov, ve druhé polovině 18. století byla černá legenda zavlečena i do ruského intelektuálního prostředí a postupně se stala nedílnou součástí obecně přijímaného diskursu. ${ }^{67}$ Právě z těchto důvodů Gumilev velmi radikálně vystupoval proti negativnímu vlivu západoevropské historiografie. Jedním z jeho hlavních cílů se stala snaha o očištění tatarského obrazu od nelichotivé pověsti barbarských nájezdníků, kteří vyplenili ruské území a dramaticky zbrzdili jeho kulturní a politický rozvoj.

Gumilevův pohled na období tatarské nadvlády a kritický postoj vůči západní Evropě lze tedy s eurasijskými myšlenkami asociovat pouze zdánlivě. $Z$ výše uvedených př́kladů je zřejmé, že ve svých výpadech souvisejících s demytizací tatarské invaze se Gumilev uchyloval $\mathrm{k}$ mnohem radikálnějším argumentům, než tomu bylo $\mathrm{v}$ př́ípadě meziválečných eurasijců. ${ }^{68}$

63 Gumilev, L. N.: God Roždenija 1380..., s. 166.

64 Termín komplementárnost tvoří nedílnou součást Gumilevovy teorie etnogeneze. Podle jeho názoru se komplementárnost projevuje na úrovni jednotlivých etnosů a zásadním způsobem formuje jejich politické a kulturní vztahy. Viz Gumilev, L: Ėtnogenez i biosfera zemli. Sankt-Peterburg 2001, s. 269-274.

65 Gumilev, L. N.: God Roždenija 1380..., s. 168.

66 Gumilev, L. N.: Ot Rusi do Rossii: očerki ètničeskoj istorii. 4-je izd. Moskv 2008, s. 160-161.

67 Gumilev, L. N.: Černaja legenda: istoriko-psichologičeskij ètjud. In: Černaja legenda. Edd. L. N. Gumilev V. Manjagin. Moskva 2006, s. 296-407, s. 15.

68 Na tuto skutečnost poukazoval P. N. Savickij v řadě dopisů adresovaných Gumilevovi na konci 50. let. Viz SLK. Sg. T-SAV. Kart. č. II/A. Korespondence přijatá od jednotlivých osob. Inv. č. 22/II Gumilev, Lev Nikolajevič, Leningrad, Praha, 1958, f. 1. Viz také MKLG-MAA. Sg. KPVKh-18928. Savickij P. N. Pis'mo L. N. Gumilevu. Praga 15 ijunja 1958, f. 2. Srov. také Bajsswenger, Martin: Jevrazijstvo v èmigracii i sovremennost': 


\section{Pozitivní reakce ruských nacionalistů na koncepce L. N. Gumileva}

Bez ohledu na všechny zmíněné narativní posuny však z pohledu některých ruských nacionalistů Gumilevovy argumenty představovaly značný potenciál, a kromě ostré kritiky získaly také významný pozitivní ohlas. Mezi osobnosti, které se přidaly na stranu Gumileva, patřil například literární historik V. V. Kožinov a spisovatel J. M. Borodaj. Obě jmenované osobnosti s Gumilevem sblížila především jejich sdílená antipatie k západní Evropě.

Borodaj se pokusil interpretovat Gumilevovy teze v roce 1981 na stránkách časopisu Priroda. V článku byla představena poněkud zjednodušená interpretace Gumilevovy koncepce etnogeneze doplněná o autorovu předtuchu nevyhnutelné konfrontace mezi Ruskem a Západem. ${ }^{69}$ Borodajovy radikální postoje a ostré antisemitské výpady proti všem aspektům západního politického systému a filozofie však výrazně překročily mantinely vytyčené Brežněvovou inkluzivní politikou a vyvolaly důraznou režimní protireakci. V listopadu 1981 došlo k obměně redakční rady zmíněného časopisu. Borodaj a Gumilev se na několik následujících let ocitli na černé listině a publikace jejich textů byla výrazně utlumená. Kromě toho došlo k definitivnímu ukončení jejich vzájemné spolupráce. ${ }^{70}$

Další text, jehož obsah vyvolal negativní reakci ze strany oficiálního režimu, publikoval V. V. Kožinov v časopise Naš sovremennik v listopadu 1981. Tématem jeho článku se stala obhajoba některých Gumilevových tezí vztahujících se právě k šestisetletému výročí kulikovské bitvy. V souladu s jeho argumenty Kožinov ostře útočil proti obecně přijímanému diskursu západoevropské historiografie a poukázal na řadu negativních důsledků plynoucích z evropocentrického pohledu na ruské dějiny. Podle jeho názoru se mělo Rusko navrátit ke svým zapomenutým asijským kořenům a osvobodit se od nežádoucího vlivu západoevropské politiky a filozofie. ${ }^{71} \mathrm{~V}$ textu Kožinova však lze vypozorovat také množství významových posunů, které zásadním zpo̊sobem zdeformovaly důležité aspekty Gumilevových tezí. Na rozdíl od Gumileva, který považoval za podstatu tzv. eurasijského super-etnosu rovnocennost a vzájemnou spolupráci ruských, turkických a řady dalších eurasijských etnosů, Kožinov přisuzoval eurasijské vlastnosti výlučně etnickým Rusům. ${ }^{72}$ Právě pod jejich vedením totiž mělo dojít ke sjednocení celé Eurasie, jejíž potenciální území se mělo do značné míry překrývat s tehdejší geografickou rozlohou Sovětského svazu.

Publikace daného textu vyvolala v prostředí ruských nacionalistů obrovský otřes a rozdělila přední redaktory časopisu Naš sovremennik na dvě znesvářené frakce. Bez ohledu na zmíněné významové a narativní posuny byl Kožinov označen za Gumilevova přívržence a propagátora tendenčních rusofobních tezí. Útoky přicházely zejména ze strany Čivilichina a Kuz'mina. Z jejich pohledu Gumilev, Kožinov a Borodaj představovali jed-

k voprosu ob idejnych vzaimootnošenijach P.N. Savickogo i L.N. Gumileva. In: Na rubeže kul'tur: russkaja èmigracija v mežvojennoj Čechoslovakii: Pamjati Mariny Jur’jevny Dostal' (1947-2011). Ed. J. P. Serapionova. Moskva 2012, 164-170., s. 168.

Borodaj, J. M.: Ètničeskije kontakty i okružajuščaja sreda, s. 82-85.

Beljakov, S. S.: Gumilev syn Gumileva, s. 565.

71 Kožinov, V. V.: I nazovet menja vsjak suščij v nej jazyk, s. 175. 
notnou linii, která nebezpečně narušovala další směřování ruského nacionalistického hnutí. $^{73} \mathrm{~V}$ konečném důsledku se kritika snesla také na tehdejšího šéfredaktora časopisu - Jurije Ivanoviče Selezněva, který schválil otištění Kožinovova př́íspěvku.

Uvedené vnitřní roztržky mezi jednotlivými ruskými nacionalisty se projevily v samotném závěru Brežněvovy vlády a představovaly završení téměř bezprecedentní publikační svobody předcházejících dvou let. Eskalující vnitřní napětí záhy upoutalo pozornost nového generálního tajemníka J. V. Andropova a posloužilo jako vhodná záminka k definitivnímu ukončení Brežněvovy nefunkční inkluzivní politiky. S př́íchodem Andropova byly předchozí snahy o integraci ruských nacionalistů do ideologického systému Sovětského svazu definitivně ukončeny. Již v březnu 1982 Andropov zahájil ostrou kampaň, jejímž výsledkem se stalo výrazné omezení publikační aktivity těchto skupin. Počet výtisků časopisu Naš sovremennik byl snížen o třetinu a J. I. Selezněv byl odvolán z pozice šéfredaktora. ${ }^{74}$ Tyto události radikálně změnily postoj ruských nacionalistů k oficiální sovětské politice a současně ještě více prohloubily vnitřní napětí mezi jednotlivými skupinami. Opoziční postoje ruských nacionalistů se významně projevily již v druhé polovině 80 . let. K jejich další eskalaci došlo v souvislosti s reformačními aktivitami M. S. Gorbačova a svého vrcholu dosáhly paralelně s kolapsem Sovětského svazu.

\section{Závěr}

Ruský nacionalismus v prostředí Sovětského svazu představoval pozoruhodný fenomén, jehož vnímání a reflexe vždy úzce souvisely se směřováním oficiální režimní ideologie. Zejména v době vlády L. I. Brežněva se ruští nacionalisté stali součástí tzv. politiky inkluze, v jejímž rámci se Brežněv snažil kontrolovat tyto kriticky naladěné skupiny intelektuálů a využít jejich aktivitu k utlumení reforem započatých N. S. Chruščovem. Již v průběhu 60. let 20. století se v rámci nacionalistického hnutí zformovalo několik samostatných skupin, kolem kterých se soustředila řada sovětských intelektuálů a akademiků. Mezi osobnosti, které se významně podepsaly na směřování radikálně orientované skupiny ruských nacionalistů (sdružené kolem časopisů Naš sovremennik a Molodaja gvardija), patří především sovětský historik a etnolog L. N. Gumilev.

Za jeden z nejdůležitějš́i aspektů Gumilevových myšlenek, které začaly rezonovat mezi ruskými nacionalisty na počátku 80 . let 20 . století, lze považovat jeho proklamované eurasijství. Navzdory režimní cenzuře Gumilev již od 80 . let 20. století zdánlivě propagoval některé myšlenky původního meziválečného eurasijského hnutí, založeného ve 20 . letech 20. století v intelektuálním prostředí tzv. bílé emigrace. Díky dlouholetému písemnému kontaktu s předními představiteli meziválečného eurasijství (geografem P. N. Savickým a historikem G. V. Vernadským) se Gumilev důsledně obeznámil s nejdůležitějšími koncepcemi tohoto hnutí. Svoje vlastní argumenty však Gumilev velmi často formuloval

73 Koževnikov, A. J.: Russkij patriotizm $i$ sovetskij socializm s. 483.

74 Cosgrove, S.: Russian nationalism and the politics of soviet literature, s. 69. 
spíše v opozici vůči názorům Savického a Vernadského a v konečném důsledku se značně odchýlil od jejich původních myšlenek.

Tato skutečnost ovšem nezabránila ruským nacionalistům vznést vůči Gumilevovi řadu ostrých obvinění právě z propagace rusofobních eurasijských koncepcí. V čele útoků se ocitl především spisovatel V. A. Čivilichin a historik A. G. Kuz'min. Oba intelektuálové v první řadě kritizovali Gumilevovy revizionisticky laděné texty, publikované v roce 1980 u příležitosti šestisetletého výročí kulikovské bitvy (1380). Historické výročí představovalo pro celou sovětskou společnost obrovský symbolický význam a v širším kontextu podnítilo řadu nových vyhraněných diskuzí nejen o minulosti ruského národa, ale také o jeho dalším směřování. Ve výsledku se kromě ostrých výpadů v ruském nacionalistickém prostředí záhy objevila také řada Gumilevových podporovatelů.

V opozici vůči Čivilichinovi a Kuz’minovi se ocitl zejména literární historik V. V. Kožinov a spisovatel J. M. Borodaj. Ve svých textech oba autoři přiblížili Gumilevovy koncepce a kladně hodnotili zejména jeho kritický postoj vưči západoevropské historiografii. I v jejich případě však při interpretaci Gumilevových myšlenek došlo k množství zásadních významových posuno̊. Zejména v textech Kožinova je možné vypozorovat tendenci směřující k umělé deformaci Gumilevových tezí tak, aby podporovaly hlavní aspekty ruského nacionalismu a v první řadě zohledňovaly vedoucí postavení ruského etnika ve formování nové potenciální eurasijské ideologie.

Eurasijské koncepce představené v Gumilevových textech však nelze jednoznačně asociovat s myšlenkami představenými v rámci původního meziválečného eurasijského hnutí tak, jak to činili výše uvedení představitelé ruského nacionalistického hnutí na počátku 80. let 20. století. „Odhalení“ Gumilevova rusofobního eurasijství v rámci ostrých výpadů ze strany Čivilichina a Kuz'mina mělo velmi povrchní a tendenční charakter. Z opačné strany pozitivní evaluace eurasijských tezí v pracích Kožinova a Borodaje vnesla do celé problematiky pouze další vrstvu zkreslení, a ještě výrazněji zkomplikovala pohled na Gumilevovy vlastní koncepce.

Ambivalentní reakce ruských nacionalistů, významně podnícené šestisetletým výročím kulikovské bitvy, měly ve výsledku dva důležité dopady. V první řadě došlo k prohloubení vnitřní roztř̌šstěnosti ruského nacionalistického hnutí a vytvoření několika nových opozičně naladěných frakcí. Jejich hlavním východiskem se stal právě postoj ke Gumilevovu proklamovanému eurasijství. Na druhou stranu, žádná ze zmíněných frakcí Gumilevovu asociaci s eurasijstvím nezpochybňovala, ačkoliv její představitelé zastávali zcela protikladné postoje.

Všechny představené argumenty v konečném důsledku jednoznačně situovaly Gumileva do pozice významného akademika, který se zasadil o oživení polozapomenutých eurasijských koncepcí pro další generaci sovětských a post-sovětských intelektuálů. Již krátce po rozpadu Sovětského svazu tuto zdánlivou kontinuitu využili zejména představitelé formujícího se neo-eurasijského hnutí usilujícího o opětovnou reintegraci roztř̌šstěného post-sovětského geopolitického prostoru. Právě pro neo-eurasijce Gumilevovy teze posloužily jako zásadní spojovník mezi původním hnutím a jeho novou podobou a napomohly k vytvoření umělé kontinuity mezi eurasijstvím 20. let 20. století a novým neo-eurasijským hnutím. 


\section{Summary}

In 1980, on the occasion of the 600th anniversary of the Kulikovo battle (1380), soviet historian and ethnologist L. N. Gumilev published two controversial articles in which he introduced his radical revision of the event. Soon his concepts gained significant attention and invoked extensive discussion in the intellectual milieu of Russian nationalists.

The main topic of the discussion was related to the Gumilev's proclaimed Eurasianism. Nationalist writer V. A. Chivlikhin and historian A. G. Kuz'min accused Gumilev of so-called russophobia and criticized the speculative nature of his texts. Nevertheless, among Russian nationalists Gumilev also gained several adherents. Positive evaluation of his ideas mainly came from the literary historian V. V. Kozhinov and writer Y. M. Borodai. Yet, Gumilev's statements cannot be unequivocally associated with those of interwar Eurasianists. In fact, "disclosure" of Gumilev's Eurasianism by Chivilikhin and Kuz'min was extremely tendentious and superficial. On the other side, the favourable response from Kozhinov and Borodai brought to the topic an additional layer of distortion.

In the upshot, such ambiguous reactions evoked two significant consequences. First, it deepened long-lasting internal rupture among Russian nationalists and split the movement into several new quarrelled groups. However, despite the vast amount of conflicting opinions, none of the groups questioned Gumilev's initial association with the interwar Eurasianism. The arguments presented by Russian nationalists eventually strengthened putative continuity between Eurasianist ideology and Gumilev's concepts and positioned him into the role of an academician who revived the original Eurasianism for future generation of soviet and post-soviet intellectuals. 
